\title{
Kalmanago gen. nov. (Microbotryaceae) on Commelina and Tinantia (Commelinaceae)
}

\section{Teodor T. Denchev ${ }^{1,2 *}$, Cvetomir M. Denchev ${ }^{1,2 *}$, Martin Kemler ${ }^{3}$ \& Dominik Begerow ${ }^{3}$}

${ }^{1}$ Institute of Biodiversity and Ecosystem Research, Bulgarian Academy of Sciences, 2 Gagarin St., 1113 Sofia, Bulgaria

${ }^{2}$ IUCN SSC Rusts and Smuts Specialist Group

${ }^{3}$ AG Geobotanik, Ruhr-Universität Bochum, ND 03, Universitätsstr. 150, 44801 Bochum, Germany

Received 16 June 2020 / Accepted 30 June 2020 / Published 2 July 2020

Denchev, T.T., Denchev, C.M., Kemler, M. \& Begerow, D. 2020. Kalmanago gen. nov. (Microbotryaceae) on Commelina and Tinantia (Commelinaceae). - Mycobiota 10: 21-37. doi: 10.12664/mycobiota.2020.10.03

Abstract. Bauerago (with B. abstrusa on Juncus as the type species) is a small genus in the Microbotryales. Its species infect plants belonging to three, monocotyledonous families, Commelinaceae (Commelina and Tinantia), Juncaceae (Juncus and Luzula), and Cyperaceae (Cyperus). There are four Bauerago species on hosts in the Commelinaceae (three species on Commelina and one on Tinantia). Bauerago commelinae on Commelina communis was studied by molecular and morphological methods. Phylogenetic analyses using rDNA (ITS, LSU, and SSU) sequences indicate that B. commelinae does not cluster with other species of Bauerago on Juncaceae. For accommodation of this smut fungus in the Microbotryaceae, a new genus, Kalmanago, is introduced, with four new combinations: Kalmanago commelinae (Kom.) Denchev et al., K. combensis (Vánky) T. Denchev et al., K. boliviana (M. Piepenbr.) T. Denchev et al., and K. tinantiae (J.C. Lindq.) T. Denchev et al. A lectotype is designated for $K$. commelinae.

Key words: Bauerago, Commelina benghalensis, Commelina communis, Commelinaceae, Kalmanago, lectotypification, Microbotryaceae, Microbotryales, new combinations, new genus, phylogeny, smut fungi, taxonomy, Tinantia

Taxonomic novelties. New genus: Kalmanago T. Denchev, Denchev, Kemler \& Begerow. New combinations: Kalmanago boliviana (M. Piepenbr.) T. Denchev, Denchev, Kemler \& Begerow, K. commelinae (Kom.) Denchev, T. Denchev, Kemler \& Begerow, K. combensis (Vánky) T. Denchev, Denchev, Kemler \& Begerow, K. tinantiae (J.C. Lindq.) T. Denchev, Denchev, Kemler \& Begerow.

\footnotetext{
*Corresponding authors: e-mails: ttdenchev@gmail.com, cmdenchev@yahoo.co.uk
} 


\section{Introduction}

In 1895-1897, the Russian botanist V.L. Komarov traveled to the Russian Far East, NE China, and Korea, and gathered an enormous number of herbarium specimens on which he described many new plant species (Komarov 1901, 1903-1904, 1905-1907). During these expeditions, Komarov collected a number of interesting plant parasitic fungi, including a smut fungus on Commelina communis, found on the border between China and Korea, near Yalu River, not far from Mao-erh-shan (currently Linjiang). Based on the gross morphological characteristics and spore shape, sizes, and ornamentation, but in the absence of information about the spore germination, Komarov placed this fungus into the genus Tilletia, with some uncertainty, and described it as 'Tilletia? commelinae' (Jaczewski et al. 1899a, b). Later, this smut fungus was recombined as Ustilago commelinae (Kom.) Zundel (Zundel 1953). Since in its modern circumscription the species of Ustilago are restricted only to host plants in the Poaceae, Denchev (2003) transferred the fungus on Commelina communis to Bauerago.

Bauerago was described by Vánky (1999) with B. abstrusa (Malençon) Vánky on Juncus gerardi Loisel. as the type species. It is a small genus in the Microbotryales comprising nine species on host plants belonging to three, monocotyledonous families, namely, Commelinaceae (on Commelina L. and Tinantia Scheidw.), Juncaceae (on Juncus L. and Luzula DC.), and Cyperaceae (on Cyperus L.). The genus was characterised by sori destroying seeds of infected plants and filling the capsules (achenes, in the case of Cyperus) with a powdery spore mass; solitary spores; absence of peridium and columellae in the sori; absence of sterile cells between the spores; host-parasite interaction by intercellular hyphae without interactions with deposits of fungal vesicles; and mature septa without pores (Vánky 2013; Begerow \& McTaggart 2018; Denchev \& Denchev 2018).

There are four Bauerago species on hosts in the Commelinaceae: B. commelinae (Kom.) Denchev, B. combensis (Vánky) Denchev, and B. boliviana M. Piepenbr. on Commelina spp., and B. tinantiae (J.C. Lindq.) Vánky on Tinantia spp. (Vánky 1994, 1999, 2008, 2011; Piepenbring 2002; Denchev 2003). The aim of the present study is to clarify the phylogenetic position of the smut fungi in Bauerago infecting hosts in the Commelinaceae. A combined approach, using molecular, morphological, and ecological data, was applied. Based on the revealed phylogenetic placement and affinities of this group of fungi in the Microbotryales, a new genus, Kalmanago, is proposed herein.

\section{Material and methods}

\section{Morphological examination}

Dried specimens from the herbarium of the Institute of Biodiversity and Ecosystem Research, Bulgarian Academy of Sciences (SOMF) were examined under a light microscope (LM). For LM observations and measurements, spores were mounted in lactoglycerol solution (w : la : $\mathrm{gl}=1: 1: 2$ ) on glass slides, gently heated to boiling point to rehydrate the spores, and then cooled. The measurements of spores are given in the form: min-max (extreme values) (mean \pm 1 standard deviation). The description below is based entirely on the specimens 
examined (excl. the information about the spore germination pattern). The shapes of spores are arranged in descending order of frequency.

\section{DNA extraction, PCR amplification, and sequencing}

For DNA extraction, spore mass from infected specimens of Commelina communis was removed. The samples were milled in the Fastprep- $24^{\mathrm{TM}}$ Sample Preparation Instrument (MP Biomedicals), using two steel beads. Genomic DNA was isolated using the myBudget Plant DNA Kit ${ }^{\mathrm{TM}}$ (Bio-Budget Technologies GmbH, Germany), according to the manufacturer's protocol (protocol 1: "Isolation of DNA from plant material using lysis buffer SLS"). PCR was performed to amplify the entire ITS or part of the ITS and parts of the LSU and SSU rDNA regions, using GoTaq ${ }^{\mathrm{TM}}$ Master Mix (Promega, USA) with primer combinations ITS1-F/ITS4 (White et al. 1990; Gardes \& Bruns 1993), 5.8S-R/ITS4 (Vilgalys \& Hester 1990; White et al. 1990), NL1/NL4 (O’Donnell 1992, 1993), and NS1/ SR7 (White et al. 1990). Standard thermal cycling conditions with annealing temperature of $52{ }^{\circ} \mathrm{C}$ were used for amplification. Five $\mu \mathrm{l}$ of PCR products were purified using ExoSAP (1:5 diluted in $\mathrm{ddH}_{2} \mathrm{O}$; New England Biolabs, USA). Amplicons were sequenced in both directions with the BigDye ${ }^{\mathrm{TM}}$ Terminator Cycle Sequencing Kit V3.1 (Applied Biosystems) on an ABI 3130xl Genetic Analyser at the Faculty of Chemistry and Biochemistry, Ruhr University Bochum, Germany. Subsequently, they were quality controlled and forward and reverse read were merged in Geneious 10.2.6 (Biomatters Ltd, Auckland). Sequences were deposited in the NCBI nucleotide database (see Table 1 for accession numbers).

\section{Phylogenetic analyses}

A multiple sequence alignment of the newly generated sequences (Table 1) and representative sequences downloaded from NCBIs GenBank (Table 2) was generated using the e-ins-i option in MAFFT v7.450 (Katoh \& Standley 2013). Ambiguous regions, as well as leading and trailing sequences, were removed using GBLOCK (Castresana 2000) implemented in SeaView (Gouy et al. 2010), whereby smaller final blocks, gap positions, and less strict flanking positions were allowed. The ITS, LSU, and SSU rDNA regions were aligned separately using MAFFT v7.305b (Katoh et al. 2002; Katoh \& Standley 2013) under the "linsi" option. The alignments were concatenated using Geneious 10.2.6 (Biomatters Ltd, Auckland). A Maximum Likelihood phylogeny was inferred by RAxML 7.3.5 (Stamatakis 2006) under the GTRGAMMA option and 1000 rapid bootstrap replicates. The resulting phylogeny was visualized in FigTree v1.4.3 (Rambaut 2012).

\section{Results}

\section{Morphology}

The results of the morphological examination by light microscopy are included in the species description and Figs 2-5.

Morphologically Bauerago commelinae can be distinguished from the type species of the genus Bauerago, B. abstrusa, by its spore germination pattern. The specific spore 


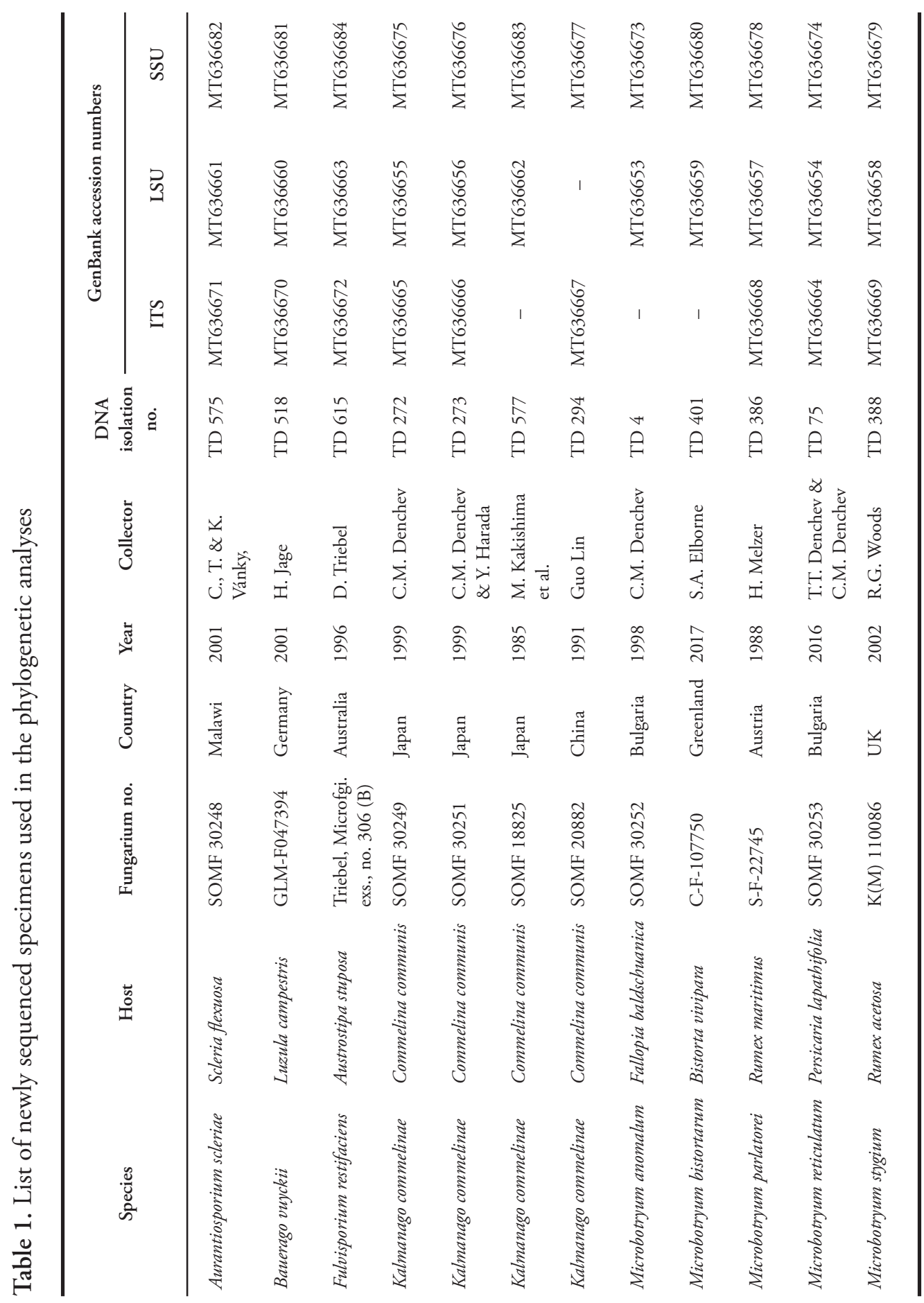


Table 2. List of sequences downloaded from GenBank

\begin{tabular}{|c|c|c|c|c|c|}
\hline \multirow{2}{*}{ Species } & \multirow{2}{*}{ Voucher no. } & \multicolumn{3}{|c|}{ GenBank accession numbers } & \multirow{2}{*}{ Reference } \\
\hline & & ITS & LSU & SSU & \\
\hline Aurantiosporium subnitens & MP1173 & - & AF009846 & - & Begerow et al. 1998 \\
\hline Bauerago abstrusa & H.U.V. 18526 & DQ238719 & EF621955 & - & $\begin{array}{l}\text { Kemler et al. 2006, } \\
2009\end{array}$ \\
\hline Bauerago vuyckii & MP2380 & DQ238720 & DQ363321 & - & $\begin{array}{l}\text { Bauer et al. 2006; } \\
\text { Kemler et al. } 2006\end{array}$ \\
\hline Fulvisporium restifaciens & H.U.V. 17637 & - & AF009860 & - & Begerow et al. 1998 \\
\hline Leucosporidium golubevii & CBS 9651 & KJ708386 & KY108283 & KJ708386 & Wang et al. 2015a \\
\hline Leucosporidium scottii & CBS 5930 & AF444495 & AF131060 & KF036682 & $\begin{array}{l}\text { Sampaio et al. 1999; } \\
\text { Scorzetti et al. 2002; } \\
\text { Liu et al. } 2015\end{array}$ \\
\hline Microbotryozyma collariae & ATCC MYA-4666 & JN849458 & JN849460 & - & Suh et al. 2012 \\
\hline Microbotryozyma collariae & ATCC MYA-4667 & JN849459 & JN849461 & - & Suh et al. 2012 \\
\hline Microbotryozyma swertiae & CGMCC2.3533 & MK050424 & MK050424 & MK050424 & Li et al. 2020 \\
\hline Microbotryum anomalum & GLM-F059392 & EF621921 & EF621960 & - & Kemler et al. 2009 \\
\hline Microbotryum betonicae & TUB 015851 & EF621924 & EF621964 & - & Kemler et al. 2009 \\
\hline Microbotryum bistortarum & TUB 015860 & EF621930 & EF621973 & - & Kemler et al. 2009 \\
\hline Microbotryum dianthorum & RUB042 & JN942224 & JN939361 & JN938659 & Schoch et al. 2012 \\
\hline Microbotryum emodensis & FO17516 & DQ238743 & AY512858 & - & $\begin{array}{l}\text { Bauer et al. 2006; } \\
\text { Kemler et al. } 2006\end{array}$ \\
\hline Microbotryum intermedium & M-0066091 & DQ238724 & EF621983 & - & Kemler et al. 2009 \\
\hline Microbotryum lychnidis-dioicae & RUB050 & JN942218 & JN939369 & JN938667 & Schoch et al. 2012 \\
\hline Microbotryum marginale & TUB 015881 & EF621940 & EF621989 & - & Kemler et al. 2009 \\
\hline Microbotryum parlatorei & В 700007574 & DQ238736 & EF621991 & - & $\begin{array}{l}\text { Kemler et al. 2006, } \\
2009\end{array}$ \\
\hline Microbotryum pustulatum & TUB 015872 & EF621947 & EF621998 & - & Kemler et al. 2009 \\
\hline Microbotryum reticulatum & CBS 101451 & KJ778630 & KJ708457 & KJ708389 & Wang et al. $2015 \mathrm{a}$ \\
\hline Microbotryum reticulatum & M-0066067 & DQ238730 & EF621999 & - & $\begin{array}{l}\text { Kemler et al. 2006, } \\
2009\end{array}$ \\
\hline Microbotryum saponariae & RUB041 & JN942252 & JN939360 & JN938658 & Schoch et al. 2012 \\
\hline Microbotryum scabiosae & CBS 176.24 & KJ778631 & KJ708458 & KJ708391 & Wang et al. 2015a \\
\hline Microbotryum scabiosae & CBS 677.93 & KJ778632 & KJ708459 & KJ708390 & Wang et al. 2015a \\
\hline Microbotryum scabiosae & TUB 015876 & EF621951 & EF622004 & - & Kemler et al. 2009 \\
\hline
\end{tabular}


Table 2. (continued)

\begin{tabular}{|c|c|c|c|c|c|}
\hline \multirow{2}{*}{ Species } & \multirow{2}{*}{ Voucher no. } & \multicolumn{3}{|c|}{ GenBank accession numbers } & \multirow{2}{*}{ Reference } \\
\hline & & ITS & LSU & SSU & \\
\hline Microbotryum scorzonerae & CBS 364.33 & KJ778633 & KJ708460 & KJ708393 & Wang et al. $2015 \mathrm{a}$ \\
\hline Microbotryum scorzonerae & CBS 685.93 & KJ778634 & KJ708461 & KJ708392 & Wang et al. $2015 \mathrm{a}$ \\
\hline Microbotryum silenes-dioicae & RUB053 & JN942216 & JN939372 & JN938670 & Schoch et al. 2012 \\
\hline Microbotryum silenes-dioicae & TUB 015864 & EF621937 & EF621985 & - & Kemler et al. 2009 \\
\hline Microbotryum silenes-inflatae & RUB033 & JN942230 & JN939352 & JN938650 & Schoch et al. 2012 \\
\hline Microbotryum stellariae & RUB056 & JN942214 & JN939375 & JN938673 & Schoch et al. 2012 \\
\hline Microbotryum violaceum & GLM-F050283 & DQ640065 & DQ640070 & - & Lutz et al. 2008 \\
\hline Microbotryum violaceum s. lat. & AFTOL-ID 1819 & DQ789984 & DQ789982 & DQ789983 & Lutzoni et al. 2004 \\
\hline Sphacelotheca cf. koordersiana & AFTOL-ID 1917 & DQ832221 & DQ832219 & DQ832220 & Lutzoni et al. 2004 \\
\hline Sphacelotheca polygoni-persicariae & MEL:2383469 & KP311404 & KP311344 & - & Schuster et al. 2016 \\
\hline Sphacelotheca polygoni-serrulati & TUB F & - & AY512884 & - & Bauer et al. 2006 \\
\hline Ustilentyloma brefeldii & TUB 012510 & DQ238745 & EF622016 & - & $\begin{array}{l}\text { Kemler et al. 2006, } \\
2009\end{array}$ \\
\hline Ustilentyloma fluitans & $\mathrm{K}(\mathrm{M})$ & KC994460 & KC994459 & - & Smith et Lutz 2014 \\
\hline Ustilentyloma fluitans & RB900 & AY212990 & AF009882 & AY124481 & Sampaio et al. 2003 \\
\hline Ustilentyloma graminis & AFTOL-ID 674 & DQ234557 & AY631901 & AY657013 & Lutzoni et al. 2004 \\
\hline Ustilentyloma graminis & CBS 6403 & AF444524 & AF189933 & NG_062670 & $\begin{array}{l}\text { Scorzetti et al. 2002; } \\
\text { Lutzoni et al. } 2004\end{array}$ \\
\hline
\end{tabular}

germination in Bauerago commelinae (as 'Ustilago commelinae') was first demonstrated by McLain (1960), later confirmed by Duran \& Safeeulla (1968) and Ingold (1989b). In this species, the phragmobasidium is 2-celled. The basidium cells neither fuse nor form sporidia. Each cell produces a long, unbranched hypha: the lower cell produces a hypha near the septum, while the upper cell produces hyphae either in an apical position or just above the septum, but never in an intermediate position. The hyphae grow to a length of several hundred micrometres without branching (Duran \& Safeeulla 1968; Ingold 1989b). The two-celled basidium with a single septum is rare in the smut fungi, for example, also observed in Moesziomyces bullatus (J. Schröt.) Vánky on Echinochloa crus-galli (L.) P. Beauv. (Ingold 1988). In these cases, the basidium is prostrate on the medium, while the two-celled basidium in Anthracoidea, a regular germination pattern in this genus, is an aerial structure (Ingold 1989a). The spore germination in Bauerago abstrusa results in a phragmobasidium on which sessile basidiospores are produced (Vánky 2013: Fig. 9F). 


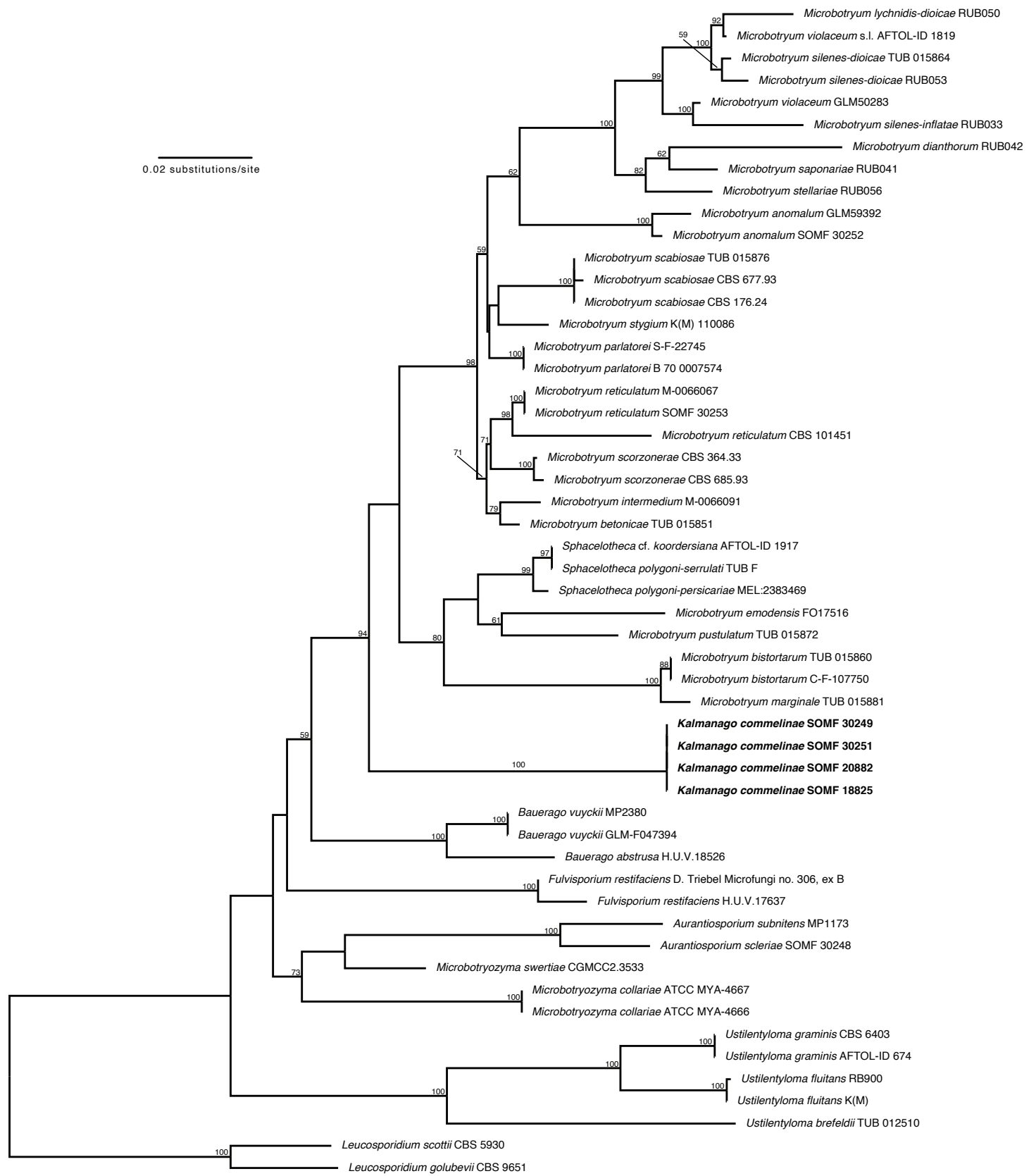

Fig. 1. Phylogenetic relationships in the Microbotryales, based on the RAxML analysis of concatenated MAFFT alignments of partial rDNA small subunit (SSU), partial rDNA large subunit (LSU), and complete rDNA internal transcribed spacer (ITS). Kalmanago commelinae is depicted in boldface. Bootstrap values of 1000 repetitions above 50 are shown above branches. The phylogeny was rooted with Leucosporidium scottii and L. golubevii. 


\section{Phylogeny}

The molecular phylogenetic analyses (Fig. 1) partially confirms previous analyses, but also indicates phylogenetic relationship not inferred by previous studies. Phylogenetic relationships within the genus Microbotryum mirror those of previous analyses, with Sphacelotheca being nested within a clade of Microbotryum species on Persicaria. The newly proposed genus Kalmanago forms the highly-supported sister group to Microbotryum and together they form the sister clade to Bauerago. However, this later relationship only has low statistical support. As in previous studies (Wang et al. 2015b) species within the family Ustilentylomataceae occur paraphyletic in our analysis, but there is no statistical support for this.

\section{Taxonomy}

Phylogenetic analyses using ITS, LSU, and SSU rDNA sequences indicates that Bauerago commelinae forms a distinct lineage and does not cluster with other species of Bauerago on Juncaceae. For accommodation of this smut fungus in the Microbotryaceae, a new genus, Kalmanago, is proposed.

Kalmanago T. Denchev, Denchev, Kemler \& Begerow, gen. nov. Index Fungorum number: IF 557798

Etymology — The genus is named in honour of Dr Kálmán Vánky (1930-), in recognition of his outstanding contribution to the taxonomy of the smut fungi in general, and to the genus Bauerago in particular. The name is derived from Kalman and Ustil-ago.

Description - Members of the Microbotryaceae R.T. Moore. Infection systemic. Sori destroying seeds of infected plants in the Commelinaceae and filling the capsules with a powdery, reddish brown to very dark reddish brown spore mass; peridium and columellae absent. Spores solitary, mainly globose and subglobose, yellowish brown to dark reddish brown; spore wall reticulate. Sterile cells lacking between the spores. Spore germination (after Duran \& Safeeulla 1968; Ingold 1989b) results in two-celled phragmobasidium; basidium cells neither fuse nor form sporidia; each cell producing a long, unbranched hypha.

Type species - Kalmanago commelinae (Kom.) Denchev, T. Denchev, Kemler \& Begerow.

Kalmanago commelinae (Kom.) Denchev, T. Denchev, Kemler \& Begerow, comb. nov. Index Fungorum number: IF 557799

Figs 2-5

Basionym: Tilletia commelinae Kom., in Jaczewski, Komarov \& Tranzschel, Fungi Rossiae Exsicc.: no. 210, 1899.

$\equiv$ Ustilago commelinae (Kom.) Zundel, Contr. Dept. Bot. School Agric. Pennsylvania State Coll. 176: 151, 1953.

$\equiv$ Bauerago commelinae (Kom.) Denchev, Mycotaxon 87: 128 [in the journal, printed by error as '129'], 2003. 


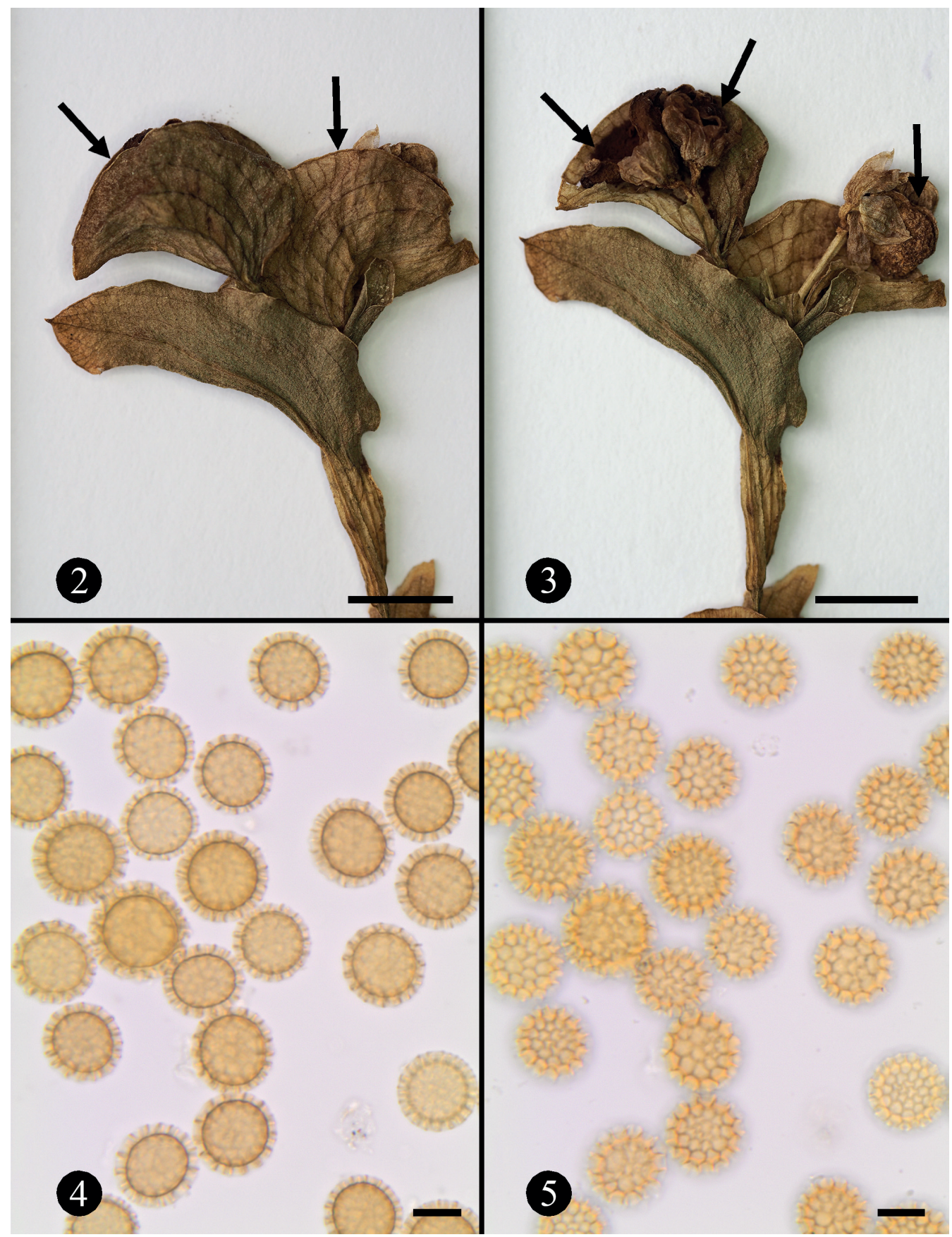

Figs 2-5. Kalmanago commelinae on Commelina communis (SOMF 30251). 2, 3. Habit (arrows in 2 show the spathae enclosing sori; arrows in 3 indicate infected capsules, visible after partial removal of the spathae). 4, 5. Spores in LM (in median and surface view, respectively). Scale bars: $2,3=0.5 \mathrm{~cm}, 4,5=10 \mu \mathrm{m}$ 
Typification - On Commelina communis: CHINA, JILIN PROVINCE, near Yalu River, not far from Mao-erh-shan (currently Linjiang), 3 Sep 1897, leg. V. Komarov, s.n. (LE 43546, lectotype, designated here; IF 557800). Isolectotypes in Jaczewski, Komarov \& Tranzschel, Fungi Rossiae Exsiccati, no. 210 (as 'Tilletia? commelinae').

Fig. 6

Infection systemic. Sori destroying the seeds, filling the hypertrophied capsules with a powdery, umber (based on the Rayner's Colour Chart; Rayner 1970) spore mass; enclosed by the spatha. Spores subglobose, globose or broadly ellipsoidal, sometimes ellipsoidal, ovoid or slightly irregular, $(14.5-) 15.5-20.5(-21.5) \times(13.5-) 14.5-19(-20)(18.4 \pm 1.0 \times$ $16.8 \pm 1.1) \mu \mathrm{m}(\mathrm{n} / 2=200)$, medium yellowish brown to medium reddish brown, reticulate; spore wall (1.9-)2.2-3.3(-3.6) $\mu \mathrm{m}$ thick (including reticulum); meshes 4-7 per spore diameter, polyhedral or irregular, (0.7-) 1.0-4.0(-4.5) $\mu \mathrm{m}$ long; muri 19-28 on equatorial circumference, in optical median view acute or subacute, (1.0-)1.2-2.3(-2.7) $\mu \mathrm{m}$ high. Spore germination (after Duran \& Safeeulla 1968; Ingold 1989b) results in two-celled phragmobasidium; basidium cells neither fuse nor form sporidia; each cell developing a long, unbranched hypha; lower cell producing a hypha near the septum, upper cell producing hyphae either in an apical position or just above the septum, but never in an intermediate position.

Specimens examined - On Commelina communis L.: JAPAN, AOMORI PREFECTURE, Hirosaki, Bunkyo-cho, Campus of Hirosaki University (Faculty of Agriculture and Life Science), $40^{\circ} 35^{\prime} \mathrm{N} 140^{\circ} 28^{\prime} \mathrm{E}, 26$ Oct 1999, leg. C.M. Denchev \& Y. Harada, s.n. (SOMF 30251); Hirosaki, 23 Oct 1999, leg. C.M. Denchev, s.n. (SOMF 30249).

Known hosts - On Commelinaceae: Commelina communis.

Distribution - Asia (Russian Far East, Japan, China), North America (U.S.A.).

Comments - Commelina communis is native to East and South East Asia, and introduced into East and South Europe and North America (Komarov 1901; Hong \& DeFilipps 2000). Kalmanago commelinae is reported (as 'Tilletia commelinae', 'Ustilago commelinae' or 'Bauerago commelinae') from the Russian Far East - Ussuri Region (Govorova 1990; Azbukina et al. 1995); Japan - Hokkaido (incl. Okushiri Island) and Honshu (Aomori, Akita, Iwate, Ibaraki, and Shizuoka prefectures) (Sydow \& Sydow 1913; Ito 1936; Kakishima 1982; Harada 1983, 1984; Vánky 1986, 1987, 1994); China (Jaczewski et al. 1899b; Guo 1988, 2000; Vánky 1992, 1994); and North America (Durán \& Fischer 1961; Vánky 1994; Farr \& Rossman 2020).

Nomenclatural notes - The name of this smut fungus was published by Komarov as 'Tilletia? commelinae', and the species was distributed in the exsiccate series Jaczewski, Komarov \& Tranzschel, Fungi Rossiae Exsiccati, under no. 210 (Jaczewski et al. 1899a, b). Although assigned to Tilletia with a question mark, this species was accepted by Komarov and he provided it with a description. Therefore, T. commelinae is considered as a validly published name (Art. 36.1., Shenzhen Code).

In volume 87 of Mycotaxon, pages $128 \& 129$ were inverted by the journal printer, incorrectly numbered, and in the wrong page order. Both combinations published there, $B$. commelinae and B. combensis, are, for nomenclatural purposes, to be considered as having been published on page 128 . 
Jaczewski, Komarov, Tranzschel LE-43546. Fungi Rossiae Exsiccati.

210. Tilletia? Commelinae Kom. nov. sp.

Soris laete castaneis, pulveraceis, fructus tegumentibus tectís, intra ovariis ortis; sporis globosis, pallide castaneis vel olivaceis 10,4$18,2 \%$ in diametro, areolis regularibus circiter $2-3,6 \mu$. altis reticulatis.

In ovariis Commelinae communis $L$.

Iu valle fl. Jalu, uon procul ab oppidulo Chinensium Mao-ell-schan. 3/14 IX. 1897.

Legit. Komarov.

Fig. 6. Kalmanago commelinae on Commelina communis (lectotypus) 
Three other species on hosts in the Commelinaceae, hitherto placed in Bauerago, also need to be relocated to Kalmanago.

Kalmanago boliviana (M. Piepenbr.) T. Denchev, Denchev, Kemler \& Begerow, comb. nov. Index Fungorum number: IF 557801

Basionym: Bauerago boliviana M. Piepenbr., Ecol. Bolivia 37: 52, 2002.

Typification - On Commelina sp., BOLIVIA, LA PAZ DEPARTMENT, Pongo de Quime, 12 Jul 1921, leg. White, no. 2256 (holotype BPI 159668; isotype BPI 159669).

For its description and illustrations, see Vánky (2011: 83-84).

Known hosts - On Commelinaceae: Commelina sp.

Distribution - South America (Bolivia). Known only from the type locality.

Kalmanago combensis (Vánky) T. Denchev, Denchev, Kemler \& Begerow, comb. nov. Index Fungorum number: IF 557802

Basionym: Ustilago combensis Vánky, Mycoscience 35: 358, 1994.

三 Bauerago combensis (Vánky) Denchev, Mycotaxon 87: 128 [in the journal, printed by error as '129'], 2003.

Typification - On Commelina benghalensis L., PAKISTAN, PUNJAB, Murree, August 1952, leg. S. Ahmad, s.n. (holotype HUV 8966).

For its description and illustrations, see Vánky (1994: 358, Figs 8-10).

Known hosts - On Commelinaceae: Commelina benghalensis.

Distribution - Asia (Pakistan). Known only from the type locality.

Kalmanago tinantiae (J.C. Lindq.) T. Denchev, Denchev, Kemler \& Begerow, comb. nov. Index Fungorum number: IF 557803

Basionym: Ustilago tinantiae J.C. Lindq., Revista Fac. Agron. Univ. Nac. La Plata, ser. 3, 29: 253, 1953.

三Bauerago tinantiae (J.C. Lindq.) Vánky, Mycotaxon 106: 162, 2009['2008'].

Typification - On Tinantia fugax Scheidw., ARGENTINA, SALTA PROVINCE, Capital Department, Quebrada de San Lorenzo, alt. 1500 m, 19 Mar 1952, leg. H. Sleumer, s.n. (holotype LPS 22062; isotype HUV 13705).

For its description and illustrations, see Vánky (2011: 87-88).

Known hosts - On Commelinaceae: Tinantia fugax, Tinantia sp.

Distribution - South America (Argentina). 
Acknowledgements. C.M. Denchev is much obliged to Prof. Yukio Harada (Hirosaki University, Hirosaki, Japan) for the facilities during his visit at the Hirosaki University, in 1999. The authors are grateful to Prof. Makoto Kakishima (University of Tsukuba, Tsukuba, Japan) for critically reading the manuscript.

\section{References}

Azbukina, Z.M., Karatygin, I.V. \& Govorova, O.K. 1995. [Class 1. Ustomycetes Moore]. - In: Z.M. Azbukina (ed.). [Cryptogamic plants, fungi and mosses of the Russian Far East]. Vol. 3. Pp. 9-205. Nauka, Saint Petersburg. (In Russian)

Bauer, R., Begerow, D., Sampaio, J.P., Weiß, M. \& Oberwinkler, F. 2006. The simple-septate basidiomycetes: a synopsis. - Mycological Research 5: 41-66.

https://doi.org/10.1007/s11557-006-0502-0

Begerow, D., Bauer, R. \& Oberwinkler, F. 1998['1997’]. Phylogenetic studies on nuclear large subunit ribosomal DNA sequences of smut fungi and related taxa. - Canadian Journal of Botany 75: 2045-2056. https://doi.org/10.1139/b97-916

Begerow, D. \& McTaggart, A. 2018. Pucciniomycotina. - In: W. Frey (ed.). Syllabus of plant families - Adolf Engler's Syllabus der Pflanzenfamilien, $13^{\text {th }}$ edn, Part 1/3: Basidiomycota and Entorrhizomycota. Pp. 17-91. Borntraeger Science Publishers, Stuttgart.

Castresana, J. 2000. Selection of conserved blocks from multiple alignments for their use in phylogenetic analysis. - Molecular Biology and Evolution 17: 540-552. https://doi.org/10.1093/oxfordjournals.molbev.a026334

Denchev, C.M. 2003. A new record and two new combinations in Microbotryales. - Mycotaxon 87: 127-130.

Denchev, T.T. \& Denchev, C.M. 2018. Contributions to the smut fungi of Africa. 4. Taxonomic reexamination and emended description of Bauerago capensis. - Mycobiota 8: 1-7. https://doi.org/10.12664/mycobiota.2018.08.01

Durán, R. \& Fischer, G.W. 1961. The genus Tilletia. Washington State University Press, Pullman, Washington.

Duran, R. \& Safeeulla, K.M. 1968. Aspects of teliospore germination in some North American smut fungi. 1. - Mycologia 60: 231-243. https://doi.org/10.1080/00275514.1968.12018565

Farr, D.F. \& Rossman, A.Y. 2020. Fungal Databases, U.S. National Fungus Collections, ARS, USDA. Available from: https://nt.ars-grin.gov/fungaldatabases/ (accessed in 6 June 2020)

Gardes, M. \& Bruns, T.D. 1993. ITS primers with enhanced specificity for basidiomycetes - application to the identification of mycorrhizae and rusts. - Molecular Ecology 2: 113-118. https://doi.org/10.1111/j.1365-294x.1993.tb00005.x

Gouy, M., Guindon, S. \& Gascuel, O. 2010. SeaView version 4: a multiplatform graphical user interface for sequence alignment and phylogenetic tree building. - Molecular Biology and Evolution 27: 221-224. https://doi.org/10.1093/molbev/msp259

Govorova, O.K. 1990. [Smut fungi of the Soviet Far East]. Institute of Biology and Soil Science, Far Eastern Branch of the Russian Academy of Sciences, Vladivostok. (In Russian)

Guo, L. 1988. The genera Ustilago and Liroa in China. - Mycosystema 1: 211-240. 
Guo, L. 2000. [Flora Fungorum Sinicorum. Vol. 12. Ustilaginaceae]. Science Press, Beijing. (In Chinese) Harada, Y. 1983. Materials for the smut flora of Japan 1. - Transactions of the Mycological Society of Japan 24: 299-306.

Harada, Y. 1984. [Plant parasitic fungi collected from the Matsumae Peninsula and the Okushiri Island, southern Hokkaido, in 1980-1983]. (In Japanese)

Hong, D.-Y. \& DeFilipps, R.A. 2000. Commelinaceae. - In: Z.-Y. Wu \& P.H. Raven (eds). Flora of China. Vol. 24 (Flagellariaceae through Marantaceae). Pp. 19-39. Science Press, Beijing, and Missouri Botanical Garden Press, St. Louis.

Ingold, C.T. 1988. Teliospore germination in some species of Ustilaginaceae. - Transactions of the British Mycological Society 91: 505-514.

https://doi.org/10.1016/S0007-1536(88)80128-1

Ingold, C.T. 1989a. The basidium of Anthracoidea inclusa in relation to smut taxonomy. - Mycological Research 92: 245-246.

https://doi.org/10.1016/S0953-7562(89)80021-8

Ingold, C.T. 1989b. Basidium development in some species of Ustilago. - Mycological Research 93: 405-412. https://doi.org/10.1016/S0953-7562(89)80033-4

Ito, S. 1936. [Ustilaginales]. - In: [Mycological flora of Japan. Vol. 2. Basidiomycetes, no. 1]. Pp. 1-148. Yokendo, Tokyo. (In Japanese)

Jaczewski, A.A., Komarov, V.L. \& Tranzschel, W.A. 1899a. Fungi Rossiae exsiccate, Fasc. 4-5 (nos. 151-250). Petropoli [St. Petersburg].

Jaczewski, A.A., Komarov, V.L. \& Tranzschel, W.A. 1899b. Fungi Rossiae exsiccate, Fasc. 5 (nos 201-250). Hedwigia 38: (113)-(114).

Kakishima, M. 1982. [A taxonomic study on the Ustilaginales in Japan]. - Memoirs of Institute of Agriculture and Forestry, University of Tsukuba 1: 1-124 + Pls I-X. (In Japanese)

Katoh, K. \& Standley, D.M. 2013. MAFFT multiple sequence alignment software version 7: improvements in performance and usability. - Molecular Biology and Evolution 30: 772-780. https://doi.org/10.1093/molbev/mst010

Katoh, K., Misawa, K., Kuma, K. \& Miyata, T. 2002. MAFFT: a novel method for rapid multiple sequence alignment based on fast Fourier transform. - Nucleic Acids Research 30: 3059-3066. https://doi.org/10.1093/nar/gkf436

Kemler, M., Göker, M., Oberwinkler, F. \& Begerow, D. 2006. Implications of molecular characters for the phylogeny of the Microbotryaceae (Basidiomycota: Urediniomycetes). - BMC Evolutionary Biology 6: 35. https://doi.org/10.1186/1471-2148-6-35

Kemler, M., Lutz, M., Göker, M., Oberwinkler, F. \& Begerow, D. 2009. Hidden diversity in the noncaryophyllaceous plant-parasitic members of Microbotryum (Pucciniomycotina: Microbotryales). Systematics and Biodiversity 7: 297-306.

http://dx.doi.org/10.1017/S1477200009990028

Komarov, V.L. 1901. [Flora Manshuriae]. Vol. 1. - Trudy Imperatorskago S.-Peterburgskago Botanicheskago Sada 20: 1-559. (In Russian)

Komarov, V.L. 1903-1904. [Flora Manshuriae]. Vol. 2. - Trudy Imperatorskago S.-Peterburgskago Botanicheskago Sada 22: 1-787 + Pls 1-17. (In Russian)

Komarov, V.L. 1905-1907. [Flora Manshuriae]. Vol. 3. - Trudy Imperatorskago S.-Peterburgskago Botanicheskago Sada 25: 1-853 + Pls 1-16. (In Russian) 
Li, A.-H., Yuan, F.-X., Groenewald, M., Bensch, K., Yurkov, A.M., Li, K., Han, P.-J., Guo, L.-D., Aime, M.C., Sampaio, J.P., Jindamorakot, S., Turchetti, B., Inacio, J., Fungsin, B., Wang, Q.-M. \& Bai, F.-Y. 2020. Diversity and phylogeny of basidiomycetous yeasts from plant leaves and soil: Proposal of two new orders, three new families, eight new genera and one hundred and seven new species. Studies in Mycology 96: 17-140.

https://doi.org/10.1016/j.simyco.2020.01.002

Liu, X.-Z., Wang, Q.M., Theelen, B., Groenewald, M., Bai, F.-Y. \& Boekhout, T. 2015. Phylogeny of tremellomycetous yeasts and related dimorphic and filamentous basidiomycetes reconstructed from multiple gene sequence analyses. - Studies in Mycology 81: 1-26.

http://dx.doi.org/10.1016/j.simyco.2015.08.001

Lutz, M., Piątek, M., Kemler, M., Chlebicki, A. \& Oberwinkler, F. 2008. Anther smuts of Caryophyllaceae: molecular analyses reveal further new species. - Mycological Research 112: 1280-1296. https://doi.org/10.1016/j.mycres.2008.04.010

Lutzoni, F., Kauff, F., Cox, C.J., Mclaughlin, D., Celio, G., Dentinger, B., Padamsee, M., Hibbett, D., James, T.Y., Baloch, E., Grube, M., Reeb, V., Hofstetter, V., Schoch, C., Arnold, A.E., Miadlikowska, J., Spatafora, J., Johnson, D., Hambleton, S., Crockett, M., Shoemaker, R., Sung, G.-H., Lücking, R., Lumbsch, T., O’Donnell, K., Binder, M., Diederich, P., Ertz, D., Gueidan, C., Hansen, K., Harris, R.C., Hosaka, K., Lim, Y.-W., Matheny, B., Nishida, H., Pfister, D., Rogers, J., Rossman, A., Schmitt, I., Sipman, H., Stone, J., Sugiyama, J., Yahr, R. \& Vilgalys, R. 2004. Assembling the fungal tree of life: progress, classification, and evolution of subcellular traits. - American Journal of Botany 91: 1446-1480.

https://doi.org/10.3732/ajb.91.10.1446

McLain, D.D. 1960. The cytology and taxonomy of Ustilago commelinae. PhD thesis, University of Illinois, Urbana. (n.v.)

O’Donnell, K. 1992. Ribosomal DNA internal transcribed spacers are highly divergent in the phytopathogenic ascomycete Fusarium sambucinum (Gibberella pulicaris). - Current Genetics 22: 213-220.

https://doi.org/10.1007/BF00351728

O’Donnell, K.L. 1993. Fusarium and its relatives. - In: J.W. Taylor \& D.R. Reynolds (eds). The fungal holomorph: mitotic, meiotic and pleomorphic speciation in fungal systematics, pp. 225-233. CAB International, Wallingford.

Piepenbring, M. 2002. Diversity, taxonomy, and ecology of plant parasitic smut fungi in Bolivia. - Ecología en Bolivia 37: 49-58.

Rambaut, A. 2012. FigTree v1.4. Available from: http://tree.bio.ed.ac.uk/software/figtree/ (accessed in 6 June 2020)

Rayner, R.W. 1970. A mycological colour chart. Commonwealth Mycological Institute, Surrey \& British Mycological Society.

Sampaio, J.P., Bauer, R., Begerow, D. \& Oberwinkler, F. 1999. Occultifur externus sp. nov., a new species of simple-pored auricularioid heterobasidiomycete from plant litter in Portugal. - Mycologia 91: 1094-1101.

https://doi.org/10.1080/00275514.1999.12061118 
Sampaio, J.P., Gadanho, M., Bauer, R. \& Weiß, M. 2003. Taxonomic studies in the Microbotryomycetidae: Leucosporidium golubevii sp. nov., Leucosporidiella gen. nov. and the new orders Leucosporidiales and Sporidiobolales. - Mycological Progress 2: 53-68.

https://doi.org/10.1007/s11557-006-0044-5

Schoch, C.L., Seifert, K.A., Huhndorf, S., Robert, V., Spouge, J.L., Levesque, C.A., Chen, W. \& Fungal Barcoding Consortium. 2012. Nuclear ribosomal internal transcribed spacer (ITS) region as a universal DNA barcode marker for Fungi. - PNAS 109: 6241-6246.

https://doi.org/10.1073/pnas.1117018109

Schuster, T.M., Stajsic, V. \& Bonito, G.M. 2016. False Polygonaceae smut: increasing knowledge about Sphacelotheca polygoni-serrulati Maire in Australia. - Muelleria 34: 83-102.

Smith, P.A. \& Lutz, M. 2014. Ustilentyloma fluitans, a new British smut. - Field Mycology 15: 8. https://doi.org/10.1016/j.fl dmyc.2014.01.005

Stamatakis, A. 2006. RAxML-VI-HPC: maximum likelihood-based phylogenetic analyses with thousands of taxa and mixed models. - Bioinformatics 22: 2688-2690.

https://doi.org/10.1093/bioinformatics/btl446

Suh, S.-O., Maslov, D.A., Molestina, R.E. \& Zhou, J.J. 2012. Microbotryozyma collariae gen. nov., sp. nov., a basidiomycetous yeast isolated from a plant bug Collaria oleosa (Miridae). - Antonie van Leeuwenhoek 102: 99-104.

https://doi.org/10.1007/s10482-012-9717-z

Sydow, H. \& Sydow, P. 1913. Ein Beitrag zur Kenntnis der parasitischen Pilzflora des nördlichen Japans. Annales Mycologici 11: 93-118.

Vánky, K. 1986. K. Vánky, Ustilaginales exsiccata. Fasc. XXI-XXII (No. 501-550). Publications from the Herbarium Ustilaginales Vánky 3: 1-17.

Vánky, K. 1987. K. Vánky, Ustilaginales exsiccata. Fasc. XXV-XXVI (No. 601-650). Publications from the Herbarium Ustilaginales Vánky 5: 1-17.

Vánky, K. 1992. K. Vánky, Ustilaginales exsiccata. Fasc. XXXIII-XXXVI (No. 801-900). Publications from the Herbarium Ustilaginales Vánky 8: 1-34.

Vánky, K. 1994. Ustaginales of Commelinaceae. - Mycoscience 35: 353-360. https://doi.org/10.1007/BF02268505

Vánky, K. 1999. The new classificatory system for smut fungi, and two new genera. - Mycotaxon 70: 35-49.

Vánky, K. 2008. Taxonomic studies on Ustilaginomycetes - 28. - Mycotaxon 106: 133-178.

Vánky, K. 2011['2012']. Smut fungi of the world. APS Press, St. Paul, Minnesota, USA.

Vánky, K. 2013. Illustrated genera of smut fungi. $3^{\text {rd }}$ edn. American Phytopathological Society Press, St. Paul, Minnesota, USA.

Vilgalys, R. \& Hester, M. 1990. Rapid genetic identification and mapping of enzymatically amplified ribosomal DNA from several Cryptococcus species. - Journal of Bacteriology 172: 4238-4246. https://doi.org/10.1128/jb.172.8.4238-4246.1990

Wang, Q.M., Groenewald, M., Takashima, M., Theelen, B., Han, P.-J., Liu, X.-Z., Boekhout, T. \& Bai, F.-Y. 2015a. Phylogeny of yeasts and related filamentous fungi within Pucciniomycotina determined from multigene sequence analyses. - Studies in Mycology 81: 27-53. 
Wang, Q.M., Yurkov, A.M., Göker, M., Lumbsch, H.T., Leavitt, S.D., Groenewald, M., Theelen, B., Liu, X.-Z., Boekhout, T. \& Bai, F.-Y. 2015b. Phylogenetic classification of yeasts and related taxa within Pucciniomycotina. - Studies in Mycology 81: 149-189.

https://doi.org/10.1016/j.simyco.2015.12.002

White, T.J., Bruns, T., Lee, S. \& Taylor, J. 1990. Amplification and direct sequencing of fungal ribosomal RNA genes for phylogenetics. - In: M. Innis, D. Gelfand, J. Shinsky \& T. White (eds). PCR protocols: A guide to methods and applications, pp. 315-322. Academic Press, San Diego. https://doi.org/10.1016/B978-0-12-372180-8.50042-1

Zundel, G.L. 1953. The Ustilaginales of the World. - Contributions, Department of Botany, School of Agriculture, Pennsylvania State College 176: i-xi + 1-410. 